„Średniowiecze Polskie i Powszechne” 2020, T. 12 (16)

ISSN 2353-9720 (wersja elektroniczna)

DOI: https://doi.org/10.31261/SPiP.2020.16.05

(c) (1) (2)

\author{
Jerzy Sperka \\ (iD https://orcid.org/0000-0002-1316-4640 \\ Instytut Historii, Uniwersytet Śląski w Katowicach
}

\title{
Księstwo karniowsko-rybnickie i jego losy do początku XVI wieku
}

$\mathrm{W}$ 2. poł. XV wieku w księstwie raciborskim będącym w rękach Przemyślidów opawskich rozpoczął się gwałtowny proces dezintegracji terytorialnej. Przyczynami były kolejne podziały dynastyczne, wydzielanie tzw. opraw wdowich (dożywocia), zastawy oraz konfiskaty królewskie. Problem ten nie został do tej pory całościowo opracowany w historiografii. Przewijał się na marginesie ogólnych prac dotyczących Śląska (zwłaszcza Górnego) ${ }^{1}$, w artykułach podejmujących kwestie związane z panowaniem poszczególnych władców i rozgrywającymi się wtedy konfliktami², a także w monografiach miast, które

${ }^{1}$ Z ważniejszych prac zob. G. BIERMann: Geschichte der Herzogthümer Troppau und Jägerndorf. Teschen 1874, s. 223-229; E. Zivier: Geschichte des Fürstentums Pless. Bd. 1. Kattowitz 1906, s. 86-146; J. Rajman: Pogranicze ślasko-matopolskie w średniowieczu. Kraków 1998, s. 212-216; R. KubICIEL: Ziemia pszczyńska i jej właściciele do połowy XVI wieku. W: Ziemia pszczyńska przez wieki. Stan badań, archiwalia, problemy badawcze. Red. A. Barciak. Suszec 2002, s. 161-163; N. Mika: Dzieje ziemi raciborskiej. Kraków 2010, s. 51-53; I. PANIC: Śląsk Cieszyński w średniowieczu (do 1528 roku). Cieszyn 2010, s. 171— 183; M. ČAPSKÝ: Górny Śląsk w okresie późnego średniowiecza (1327-1526). W: Historia Górnego Śląska. Polityka, gospodarka i kultura europejskiego regionu. Red. J. BAHLCKe, D. Gawrecki, R. KacZmareK. Gliwice 2011, s. 130-135.

${ }^{2}$ H. Grotefend: Stammtafeln der schlesischen Fürsten bis zum Jahre 1740. Breslau 1889, s. 58-59; F. СносноLatÝ: Genealogie opavských Přemyslovců 1255-1525. „Listy Genealogické a Heraldické Společnosti v Praze. Acta Genealogica ac Heraldica” 1978, Ř. 6, s. 149-153; F. Kopetzky: Zur Geschichte und Genealogie der Přemyslidischen Herzoge von Troppau. „Archiv für österreichische Geschichte“ 1869, Bd. 41, s. 76-93; T. KREJčík: Přemyslovci Opavští. V: Biografický slovník Slezska a severní Moravy. Č. 4. Opava-Ostrava 1995, s. 102-107; Książęta i księżne Górnego Ślaska. Red. A. Barciak. Katowice 1995, passim; J. PolaK: Poczet panów i książąt pszczyńskich. Cz. 1. Pszczyna 2007, s. 14-36; T. Górecki, M. WieczoreK: 
w przeszłości odgrywały rolę centrów władzy książęcej³. Biorąc jednak pod uwage — zwłaszcza w przypadku starszej historiografii (chociaż nie tylko) nie zawsze pełne wykorzystanie dostępnych źródeł, dowolność i często ogólnikowość wysuwanych sądów, a co za tym idzie: rozbieżności interpretacyjne i faktograficzne, wydaje się konieczne, aby patrząc kompleksowo na interesujący nas problem, podjąć próbę usystematyzowania naszej wiedzy w tym zakresie.

W 1437 roku (15 października) książęta raciborscy Mikołaj V i Wacław II, po kilkunastu latach od śmierci ich ojca Jana II Żelaznego (zm. 1424), dokonali podziału rządzonego dotąd wspólnie księstwa. Terytorium to składało się z dawnego księstwa raciborskiego, korzeniami sięgającego jeszcze końca XIII wieku, przejętego w 1337 roku — po wymarciu Piastów — przez Przemyślidów opawskich, oraz okręgu karniowskiego, będącego częścią księstwa opawskiego, który w podziale w 1377 roku otrzymał Jan I, ojciec Jana Żelaznego. Mikołaj i Wacław, dzieląc schedę po ojcu, dokonali tego za pośrednictwem czynnika społecznego, a mianowicie dziewięciu rycerzy (Hanusza Kosierza z Żywocic, Bielika Kornicza z Bogumina, Pawła z Zatora, Piotra z Chuchelnej, starosty karniowskiego, Jaśka Rubena z Rakowa, starosty raciborskiego, Pawła z Lichnowa, Mikołaja z Leszczyn, Hanusza Klemy z Ligoty i Janka z Białej) reprezentujących ziemię raciborską, karniowską i rybnicką, a więc trzy podstawowe części (okręgi) księstwa raciborskiego. W wyniku podziału

Książęta Górnego Śląska. Wybór postaci. Żory 2008, s. 133-155 (ujęcie popularne); M. C̆APSKÝ, D. RADEK: Paralela ke zhoreleckému vévodství? K rodové politice Matyáše Korvina v Horním Slezsku. „Historie - Otázky — Problémy” 2015, 1 (7), s. 175-177; J. SPERKA: Tragiczne losy księcia rybnickiego Wactawa III (zm. 1478). Epizod z dziejów rywalizacji między Jagiellonami a Maciejem Korwinem o koronę czeska. „Studia z Dziejów Średniowiecza” 2016, T. 20, s. 253-271; TenżE: Matżeństwa Mikołaja V księcia opawsko-raciborskiego pana na Rybniku (zm. 1452 r.). W: Silesia - Polonia - Europa. Red. J. SPERKA. Katowice-Bielsko-Biała 2019, s. 249—262; J. SPERKa: Koligacje rodzinne Przemyślidów opawskich linii raciborskiej z możnowładztwem Królestwa Polskiego do początku XVI wieku. „Średniowiecze Polskie i Powszechne" 2019, T. 11 (15), s. 183-212.

${ }^{3}$ F. IDzikowski: Geschichte Stadt und ehemaligen Herrschaft Rybnik in Oberschlesien. Breslau 1861, s. 44-47; A. Weltzel: Geschichte der Stadt und Herrschaft Ratibor. Ratibor 1881, s. 79-109; TenżE: Historia miasta Żory na Górnym Śląsu. Żory 1997 (przekład na podstawie: A. Weltzel: Geschichte der Stadt Sohrau in Oberschlesien. Sohrau 1888), s. 43-60; L. Musioe: Pszczyna. Monografia historyczna. Katowice 1936, s. 40-44; G. Hyckel: Geschichte der Stadt Ratibor. Das Mittelalter. Augsburg 1956, s. 112-119; W. DzIEwulski: Dzieje Raciborza od najdawniejszych czasów do zaboru Ślaska przez Prusy. W: Szkice z dziejów Raciborza. Katowice 1967, s. 71-75; P. KouŘil, M. WinODA, D. Prix: Hrady českého Slezska. Brno-Opava 2000, s. 520—541; I. PANIC: Żory pod rzadami Przemyślidów i Habsburgów. Z badań nad historiq miasta w latach 1327-1742. Żory 2002, s. 87-101; Opava. Edd. K. Müller, R. ŽÁčeK. Praha 2006, s. 115-117; J. Sperka: Pszczyna i ziemia pszczyńska - dzieje polityczne do 1517 roku. W: Pszczyna. Monografia historyczna. Red. R. KaCzMAReK, J. SPerka. Pszczyna 2014, s. 90-106; J. Sperka: Do 1532 roku. W: Rybnik. Dzieje miasta i jego dzielnic. Red. Z. Hojka, B. KLOCH. T. 1. Rybnik 2017, s. 141-163. 
starszy z braci, Mikołaj V, zatrzymał: Karniów, Vartnov, Bruntal, Baborów, Wodzisław, Rybnik i Pszczynę wraz z przynależnościami. Ten ostatni okręg miał mu jednak przypaść dopiero po śmierci matki - księżnej Heleny Korybutówny, która miała na nim zapisane dożywocie (wiano). Młodszemu, Wacławowi II, przypadł jedynie Racibórz z okręgiem i zwierzchnictwo nad leżącymi w okręgu rybnickim Żytną i Pilchowicami, własnością Mikołaja Jejkowskiego z Jejkowic. Te dwie wsie były rekompensatą za Tworków położony w okręgu raciborskim, którego właściciel Hanusz Klema z Ligoty podlegał władzy księcia Mikołaja. Obydwaj bracia mieli prawo korzystać z terenów łowieckich koło klasztoru Cystersów w Rudach, kamieniołomów w Radoszowach koło Rybnika i miejscowych kopalń srebra. Między braci rozdzielono również zobowiązania wobec wierzycieli (w tym także wobec służby i zaciężnych), których należało spłacić ${ }^{4}$.

W wyniku podziału ukształtowały się zatem dwa nowe organizmy polityczne: księstwo raciborskie i karniowsko-rybnickie, chociaż panujący w nich młodzi Przemyślidzi, Mikołaj i Wacław, nadal używali dotychczasowej tytulatury książąt Opawy i Raciborza 5 . Terytorium niewielkiego księstwa raciborskiego przez następne 40 lat nie uległo zmianom. Książę Wacław II panował w nim aż do śmierci w 1456 roku. Później, przez kilka lat, władzę sprawowała wdowa, księżna Małgorzata Szamotulska, a po osiągnięciu pełnoletniości tron książęcy przejął ich jedyny syn Jan IV Młodszy (zm. 1493)

Inaczej przedstawiała się sytuacja w księstwie karniowsko-rybnickim, w którym władzę sprawował Mikołaj V. Jeszcze przed podziałem przeprowadzonym w 1437 roku książę powiększył domenę książęcą, anektując dominikankom raciborskim klucz baborowski składający się z miasteczka Baborów (dawniej: Baworów) i przyległych wsi ${ }^{7}$ Po śmierci matki, Heleny (zm. 1449), dołączył do swego władztwa okręg pszczyński, w skład którego wchodziły miasto i zamek w Pszczynie, miasteczka Mikołów, Bieruń oraz Mysłowice

${ }^{4}$ Centrum Informacji Naukowej i Biblioteka Akademicka w Katowicach: Copiarius monasteri ad S. Venceslaum. Diplomatarius Silesiacarum (dalej: CMV) — mikrofilm syg. Mf. 166, 1-2 (oryginał w Bibliotece Narodowej w Pradze, sygn. 6 XVI 8), s. 605v. $-607=$ CDSil, Bd. 6, s. 59-61, nr 195 (regest) = LBS, T. 2, s. 394 (regest). Szerzej na ten temat zob. P. Kouřıl, M. Winoda, D. Prix: Hrady českého Slezska..., s. 520-521; J. Sperka: Do 1532 roku..., s. 141-142; TenżE: Małżeństwa Mikołaja V..., s. 250—251.

${ }^{5} \mathrm{Na}$ temat tytulatury używanej przez Przemyślidów, książąt Opawy i Raciborza zob. I. Pietrzyk: Kancelaria i dokument Przemyślidów opawskich w XIV-XV wieku. Katowice 2008, s. 66-67; J. Sperka: Tragiczne losy księcia rybnickiego Wactawa III..., s. 257-258.

${ }^{6}$ H. Grotefend: Stammtafeln der schlesischen Fürsten..., s. 21, tab. 12; J. Sperka: Koligacje rodzinne Przemyślidów opawskich linii raciborskiej..., s. 198-211 (tam źródła i literatura przedmiotu).

7 Ratiborer Chronik. Hrsg. A. Weltzel. „Zeitschrift des Vereins für Geschichte und Alterthum Schlesiens“ 1862, Bd. 4, s. 118, 123-124. 
z przynależnościami ${ }^{8}$. Problemem był natomiast zamek Vartnov (z przynależnymi wsiami), który ojciec Mikołaja, Jan Żelazny, w 1421 roku kupił - może pod naciskiem - od Štěpána młodszego z Vartnova. Skutkowało to późniejszymi sporami o te dobra i ostatecznie doprowadziło do tego, że w 1447 roku Mikołaj V nadał je za zasługi Bernardowi Birkovi z Násile?

Mimo że książę na wystawianych dokumentach tytułowany był księciem Opawy i Raciborza ${ }^{10}$, to w powstałej w XV wieku Kronice raciborskiej określano go konsekwentnie przydomkiem „rybnicki” (Reibnicensis) albo „,z Rybnika" (de Reibnig) ${ }^{11}$. Sugerowałoby to, że miasto, a raczej zamek w Rybniku był jego główną siedzibą. Tam zresztą książę zmarł 22 grudnia 1452 roku, w wyniku zarazy, która dotknęła w tym czasie terytoria Śląska, ziemi wieluńskiej i krakowskiej ${ }^{12}$.

Mikołaj V był dwukrotnie żonaty. Pierwszą żoną została Małgorzata, wdowa po Hanuszu (Januszu, Janie) Klemie z Ligoty, wasalu księcia. Z tego małżeństwa narodziło się troje dzieci: Jan (Hanusz) III Starszy, Wacław zwany Głupim (Głuptawym) ${ }^{13}$ oraz Barbara, która w końcu lat 70. (jednak przed 9 października 1483 roku) wyszła za Jana (Janusza) IV oświęcimskiego ${ }^{14}$. Po śmierci pierwszej żony, Małgorzaty (zm. zapewne w 1450 roku), Mikołaj V na

${ }^{8}$ Księżna Helena miała wydzieloną przez męża Jana Żelaznego oprawę wdowią (wiano) w 1407 r. i rozszerzoną w 1412 r. - KDP, T. 4, nr 15-17; szczegółowo na ten temat zob. J. TęGowski: Pierwsze pokolenia Giedyminowiczów. Poznań-Wrocław 1999, s. 113; J. Sperka: Pszczyna i ziemia pszczyńska..., s. 89-90.

Nie znalazłem potwierdzenia informacji podanej przez F. Сносноlatego (Genealogie opavských Přemyslovců..., s. 150), jakoby Hyncík z Wierzbna (Vbrna) miał w 1447 r. (nota bene zmarł już w 1445 r.) wziąć w zastaw połowę ziemi karniowskiej z Bruntalem. Dobra te dostały się w ręce Wierzbińskich dopiero w latach 70. XV w. — zob. J. PilnáčEK: Rody starého Slezska. Díl. 1-5. Brno 1991 - tutaj: Díl. 5, s. 1391-1392; J. STiBor: Bruntálśtí z Vrbna. V: Biografický slovník Slezska a severní Moravy. Č. 10. Ostrava 1998, s. 27-29.

9 P. KouřIl, M. Winoda, D. Prix: Hrady českého Slezska..., s. 353-354, 521.

${ }^{10}$ CDSil, Bd. 2, s. 189, nr 82 (28 XII 1444); F. IDZIKowski: Geschichte Stadt..., s. $83=$ A. Trunkhardt: Kronika Rybnicka. (Dzieje miasta Rybnika i dawniejszego państwa rybnickiego na Górnym Śląsu na podstawie wydanej w 1861 r. Kroniki Franciszka Idzikowskiego). Rybnik 1925, s. 55 (8 VII 1445); CDSil, Bd. 2, nr 59 = Katalog średniowiecznych dokumentów przechowywanych w Archiwum Państwowym we Wrocławiu. Wyd. R. Stelmach. WrocławRacibórz 2014, nr 10698 (15 VI 1446); A. Weltzel: Historia miasta Żory..., s. 47 (4 IV 1451).

${ }^{11}$ Ratiborer Chronik..., s. 118, 121.

${ }^{12}$ H. Grotefend: Stammtafeln der schlesischen Fürsten..., tab. 12; W. DworzaczeK: Genealogia. T. 2. Warszawa 1959, tab. 11. Problem daty śmierci księcia Mikołaja omawiam szczegółowo w artykule: Małzeństwa Mikołaja V księcia opawsko-raciborskiego..., s. 257. Na temat zarazy zob. Annales, lib. 12 [2003], s. 137; Roczniki, ks. 12 [2004] s. 152-153.

${ }_{13}$ Annales, lib. 12 [2003], s. 150; Roczniki, ks. 12 [2004], s. 167-168; Ratiborer Chronik..., s. 121, 123; KDP, T. 4, nr 46, 85; J. SPERKA: Tragiczne losy księcia rybnickiego Wackawa III..., s. 255; TENŻE: Małżeństwa Mikołaja V księcia opawsko-raciborskiego..., s. 251-253.

${ }^{14}$ H. Grotefend: Stammtafeln der schlesischen Fürsten..., s. 21, tab. 12; W. DworzaCZEK: Genealogia..., tab. 11; K. JAsiŃski: Rodowód Piastów śląskich. Kraków 2007, s. 649. 
początku 1451 roku poślubił Barbarę Rokenberg, bogatą mieszczkę krakowską, ale mającą szlacheckie korzenie ${ }^{15}$. Z tego związku urodzili się: Mikołaj, który zmarł w młodości, oraz Małgorzata (Machna), która w latach 1482-1484 została żoną Kazimierza, księcia oświęcimsko-zatorskiego (zm. 1490-1492); zmarła w 1508 roku (między 4 stycznia a 23 lipca) ${ }^{16}$.

Ponieważ w chwili śmierci Mikołaja V (22 grudnia 1452 roku) jego synowie byli nieletni, o opiekę nad nimi, a co za tym idzie - o opiekę nad księstwem, wybuchł konflikt między bratem zmarłego, księciem raciborskim Wacławem II, a wdową po zmarłym, Barbarą Rokenberg. Ta ostatnia zamierzała bowiem - wzorem swej poprzedniczki Heleny — rządzić księstwem do usamodzielnienia się synów zmarłego. Wacław wykorzystał jednak stare prawo zwyczajowe, dające mu jako najbliższemu krewnemu prawo do opieki nad bratankami (i ich księstwem) do czasu, kiedy ci osiągną pełnoletniość. Konsekwencją tego było przejęcie władzy — zapewne jeszcze w 1453 roku na większości terytorium, które należało wcześniej do zmarłego Mikołaja V. Wyjątek stanowiła ziemia pszczyńska, będąca dożywociem księżnej Barbary; prawa do ziemi pszczyńskiej podkreślała, dodając do tytulatury księżnej opawskiej i raciborskiej określenie „pani na Pszczynie” (Herinn de Pless). Wacław nie pogodził się jednak z takim stanem rzeczy i jesienią 1454 roku rozpoczął konflikt z Barbarą po tym, jak ta nie wpuściła go do Pszczyny. Próbował zająć miasto siłą i przez tydzień oblegał je $\mathrm{z}$ dużą armią, ale nie osiągnąwszy sukcesu, ostatecznie pogodził się z wdową ${ }^{17}$.

Po śmierci Wacława II raciborskiego w 1456 roku (29 października) rządy w księstwie karniowsko-rybnickim wróciły w ręce spadkobierców Mikołaja V, a sprawowali je początkowo wspólnie Barbara i jej pasierb Jan III Starszy. Razem reprezentowali księstwa karniowskie, rybnickie i pszczyńskie (,ducatibus nostris [...] Krnowiensi, Ribniczensi et Plesnensi”), podpisując 29 czerwca 1457 roku w Cvilínie (koło Karniowa) pokój z królem polskim Kazimierzem Jagiellończykiem na okres roku ${ }^{18}$. Po pewnym czasie - nie wiadomo jednak, kiedy i jakie były tego przyczyny — popsuły się stosunki Barbary z Janem III. Młody książę — podobnie jak zmarły stryj — nie chciał dalej tolerować księżnej w Pszczynie. Nie będąc w stanie zająć miasta i zamku zbrojnie, wymyślił podstęp. 12 czerwca 1462 roku jego ludzie przebrani za pielgrzymów podąża-

${ }_{15}$ Annales, lib. 12 [2003], s. 150; Ratiborer Chronik..., s. 118; J. SPerka: Matżeństwa Mikołaja V księcia opawsko-raciborskiego..., s. 254-255.

${ }^{16}$ H. GRotefend: Stammtafeln der schlesischen Fürsten..., tab. 12; K. JAsiŃSKi: Rodowód Piastów śląskich..., s. 655-656; F. KIRYK: Matgorzata (Machna). W: PSB, T. 19, s. 443-444; J. SPerka: Matżeństwa Mikołaja V księcia opawsko-raciborskiego..., s. 257-260.

${ }_{17}$ Ratiborer Chronik..., s. 118; E. Zivier: Geschichte..., s. 100; R. KubICIEL: Ziemia pszczyńska..., s. 170; J. SPerka: Pszczyna i ziemia pszczyńska.., s. 93, 140 (przyp. 106); TeNŻE: Matżeństwa Mikołaja V księcia opawsko-raciborskiego..., s. 258.

${ }_{18} \mathrm{KDP}, \mathrm{T} .4, \mathrm{nr} 46$. 
jących na targ do Wodzisławia weszli do obwarowanego miasta, a następnie je opanowali. Zmuszona do opuszczenia Pszczyny Barbara osiadła w rodzinnym Krakowie, gdzie spędziła ostatnie lata życia; zmarła po 8 stycznia 1470 roku $^{19}$.

Książę Jan III Starszy sprawował początkowo władzę w księstwie samodzielnie, nie dopuszczając do współrządów młodszego brata Wacława III $^{20}$. $\mathrm{Z}$ czasem zapewne się to zmieniło, albowiem 19 lutego 1465 roku starosta karniowski Wawrzyniec z Bytkowa, występując przed tamtejszym sądem ziemskim, reprezentował już obydwu braci ${ }^{21}$. Książę Jan rezydował z pewnością często w Rybniku; z tym miastem łączył go bowiem Jan Długosz, wymieniając — jako Jana rybnickiego — wśród gości na chrzcinach córki króla Kazimierza Jagiellończyka Elżbiety 16 maja 1465 roku w Krakowie ${ }^{22}$. Do podziału księstwa między braćmi doszło niedługo po tym wydarzeniu, gdyż z 9 lutego 1466 roku pochodzi pierwszy samodzielny dokument Wacława III odnoszący się do jego władztwa ${ }^{23}$. W wyniku podziału — jak wskazują na to późniejsze źródła - Jan III zatrzymał dla siebie Karniów, Bruntal i Wodzisław, natomiast Wacław III przejął Rybnik, Żory i Pszczynę z przynależnościami. Dobrami baborowskimi, zajętymi dominikanom raciborskim jeszcze przez ich ojca, bracia podzieli się po połowie ${ }^{24}$. Powstały zatem dwa niewielkie księstwa - karniowskie i rybnickie, tak też potocznie określano panujących tam książąt, chociaż oficjalnie używali oni tytulatury książąt Opawy i Raciborza. Czasem jedynie, stosownie do sytuacji, dodawali określenie: „pan na Karniowie" 25 — w przypadku Jana, lub „,pan na Rybnik albo Pszczyny” —

${ }^{19}$ Ratiborer Chronik..., s. 121; J. Sperka: Pszczyna i ziemia pszczyńska..., s. 95-95 (tu skorygowana datacja wydarzeń w stosunku do dawniejszej literatury przedmiotu); Tenże: Matżeństwa Mikołaja V księcia opawsko-raciborskiego..., s 259-260 (tu o dalszych losach księżnej).

${ }^{20}$ Potwierdzają to dokumenty wystawiane przez niego samodzielnie w 1462 i $1463 \mathrm{r}$. E. Zivier: Geschichte..., s. 184, nr 11 = Listinář Těšínska. Codex diplomaticus ducatus tesinensis. Sv. 3: 1460-1495. Zprac. E. NĚMeC. Český Těšín 1960, nr 230; L. MusioŁ: Pszczyna..., s. 541-542; J. Sperka: Tragiczne losy księcia rybnickiego Wactawa III..., s. 256-257.

${ }^{21}$ P. KouŘil, M. Winoda, D. Prix: Hrady českého Slezska..., s. 522.

22 Annales, lib. 12 [2005], s. 110; Roczniki, ks. 12 [2006], s. 120-121 (wydawcy w przyp. 54 niepotrzebnie poprawiają Jana Długosza, zarzucając mu pomyłkę, i sugerują, że powinien być tam Wacław, późniejszy książę rybnicki).

${ }^{23}$ AP Katowice, Oddział w Pszczynie: Archiwum Ksiąząt Pszczyńskich, dok. sygn. II-15; E. Zivier: Geschichte..., s. 186, nr 12 (dokument został wystawiony w Rybniku, a dotyczył rozstrzygnięcia sporu między Anną z Pielgrzymowic i jej synem Mikołajem a Piotrem Judaszem z Golasowic o prawo patronatu w kościele w Golasowicach, które książę przyznał Piotrowi). Błędnie podaje I. PANIC (Żory pod rządami Przemyślidów..., s. 91), że do podziału między Janem Starszym a Wacławem doszło już w 1455 r.

${ }^{24}$ Ratiborer Chronik..., s. 123; R. Kubiciel: Ziemia pszczyńska..., s. 171; J. SPERKA: Pszczyna i ziemia pszczyńska..., s. 95; TenżE: Do 1532 roku..., s. 150-151. Odnośnie do dóbr baborowskich zob. dalej przyp. 43.

${ }^{25}$ Archiv český, čili staré písemné pámatky české i moravské. Díl. 4. Ed. F. PalackÝ. Praga 1846, nr 16 (Hanuš kneže Opawský a Ratiborský pan Krnowský); Archiv český, čili staré 
w przypadku Wacława ${ }^{26}$. Natomiast tego ostatniego współczesny mu Jan Długosz w swoich Rocznikach konsekwentnie nazywał księciem rybnickim ${ }^{27}$.

Początek samodzielnych rządów Wacława III zbiegł się z kolejnym konfliktem o koronę czeską. Jak się miało okazać, spór ten nie tylko zaważył na jego życiu, ale także znacząco wpłynął na losy jego niewielkiego księstwa. Kiedy w 1469 roku panowie morawscy wybrali w Ołomuńcu na króla czeskiego Macieja Korwina, Wacław rybnicki, który dotąd stał wiernie przy Jerzym z Podiebradów, opowiedział się za władcą Węgier i 8 czerwca wraz z częścią książąt śląskich złożył mu hołd we Wrocławiu ${ }^{28}$. Latem tego roku wspierał go też militarnie, wraz z Przemkiem II cieszyńskim, w walkach na Morawach. Jednak już wiosną 1470 roku Wacław rybnicki wszczął wojnę ze swym niedawnym sojusznikiem księciem cieszyńskim oraz ze swoim krewnym Janem głubczyckim $^{29}$. W konflikcie tym szukał pomocy u króla Macieja Korwina, ale jej nie uzyskał, co najpewniej skłoniło go do przejścia na stronę Jagiellonów. Kiedy więc w końcu maja 1471 roku ruszyła wyprawa królewicza Władysława, książę rybnicki przyłączył się do niej. Wraz z nim w szeregach Jagiellończyka stanęli jeszcze Jan IV Młodszy raciborski, Kazimierz II cieszyński oraz

písemné pámatky české i moravské. Díl. 5. Ed. F. PALACKÝ. Praga 1862, nr 14 (Hanuš starši Opawský a Ratiborský).

26 AP Katowice, Oddział w Pszczynie: Księga radziecka miasta Pszczyny (1466-1544), sygn. M Pna 369, s. 2-3, 11-12, 5-6v., 14-20; L. Musiot: Najstarszy protokót miasta Pszczyny. „Roczniki Towarzystwa Przyjaciół Nauk na Śląsku” 1931, T. 3, s. 336-339; AP Katowice, Oddział w Pszczynie: Archiwum Książat Pszczyńskich, dok. sygn. II-15, 16, 18; CMV, nr 49, 501, s. 83-83v., 597—598 = CDSil, Bd. 6, nr 292, 293, s. 96-97 (regesty); E. Zivier: Geschichte..., s. 104-105; F. Zimmermann: Beyträge zur Beschreibung von Schlesien. Bd. 2. Brieg 1783, s. 55 (dux Oppavie et Ratiborie; dux Oppavie et Ratiborie et dominus in Blsschczyna; knize oppavske a ratiborske; knize Oppavske a Ratiborske a pan Blssczinsky; dux Oppaviensis, Rathiboriensis et Rybniczensis, dux Ribnicensis); J. SPERKA: Tragiczne losy księcia rybnickiego Wacława III..., s. 258.

${ }_{27}$ Annales, lib. 12 [2005], s. 242, 272, 301, 330, 356; Roczniki, ks. 12 [2006], s. 253, 284, 316, 345-346, 372.

${ }^{28}$ P. Eschenloher: Historia Wratislaviensis. Hrsg. H. Margraf. In: SRS. Bd. 7. Breslau 1872, s. 203 (kronikarz podał, że wszyscy książęta górnośląscy złożyli hołd, ale nie wymienił ich imiennie); Annales, lib. 12 [2005], s. 234; Roczniki, ks. 12 [2006], s. 244-245. Na temat elekcji Korwina i jego polityki wobec książąt górnośląskich zob.: A. Kalous: Matyáš Korvín (1443-1490). Uherský a český král. České Budějovice 2009, s. 135-138; M. ČAPSKÝ, D. RADEK: Paralela ke zhořeleckému vévodství?..., s. 174-178; P. KouŘıl, M. WiHOdA, D. Prix: Hrady českého Slezska..., s. 523; F. PALACKÝ: Dějiny národu českého v Čechách a v Moravě. Praha 1908, s. 992; J. Sperka: Tragiczne losy księcia rybnickiego Wacława III..., s. 259.

${ }_{29}$ Politische Correspondenz Breslaus im Zeitalter des Königs Matthias Corvinus (14691479). Hrsg. B. Kronthal, H. Wendt. In: SRS. Bd. 13. Breslau 1893, s. 17, nr 24; J. Sperka: Kazimierz Jagiellończyk wobec książąt i księstw górnośląskich. Zarys relacji politycznych. W: Jagiellonowie $i$ ich świat. Dynastia królewska $w$ drugiej połowie XV $i$ w XVI wieku. Red. B. Czwojdrak, J. Sperka, P. WęCowski. Kraków 2016, s. 109; J. Sperka: Tragiczne losy księcia rybnickiego Wactawa III..., s. 260. Bałamutnie o tych wydarzeniach I. PANIC: Żory pod rządami Przemyślidów..., s. 92—94; TenżE: Śląsk Cieszyński..., s. 174—175. 
książęta oświęcimscy: Przemysław toszecki, Janusz gliwicki i Jan zatorski ${ }^{30}$. Poparcie udzielone przez nich Jagiellończykowi nie przełożyło się jednak na poprawę ich wzajemnych relacji i nie zapobiegło dalszej eskalacji konfliktu na Górnym Śląsku. Jak podaje pod rokiem 1471 współczesny rozgrywającym się wydarzeniom Jan Długosz: „[...] książęta: cieszyński Przemysław, raciborski Jan, gliwicki Janusz z jednej, a rybnicki Wacław z drugiej strony, wyniszczali się wzajemnie prywatną wojną"31. Wreszcie w konflikt włączył się król Maciej Korwin i z jego rozkazu w marcu 1473 roku w Nysie zawiązał się sojusz przeciw Wacławowi. Jego uczestnicy przystąpili do niego z powodu szalonych występków Wacława, których dopuszczał się wobec sąsiednich książąt, a wyprawę przeciw księciu rybnickiemu poprowadził Wiktoryn z Podiebradów, książę ziębicki. Wraz z nim ruszyli książęta: Przemysław II cieszyński, Jan głubczycki, Jan IV Młodszy raciborski, a pomocy udzielili Mikołaj I opolski, biskup wrocławski Rudolf oraz miasta — Wrocław i Świdnica ${ }^{32}$. W wyprawie wziął udział także Wacław Kropacz młodszy z Niewiadomia, poddany Wacława III, ale będący na służbie króla węgierskiego ${ }^{33}$. Najeźdźcy przez trzy miesiące plądrowali księstwo rybnicko-pszczyńskie, ale udało im się zdobyć tylko nieobwarowane miasto Rybnik i najpewniej tamtejszy zamek. Książę Wacław obronił Pszczynę, a napastnicy utknęli ostatecznie pod Żorami mającymi solidne mury, których obroną dowodził polski rycerz Jan Kresa. Wsparł bowiem księcia Wacława król Kazimierz Jagiellończyk, który przekazał 3000 florenów na zaciężnych, a odsiecz przyprowadził Jakub z Dębna, kanclerz i starosta krakowski, z którym książę od dłuższego czasu miał dobre relacje ${ }^{34}$. W dniu 6 czerwca 1473 roku pod Żorami został zawarty pokój, który co prawda

${ }^{30}$ Annales, lib. 12 [2005], s. 272; Roczniki, ks. 12 [2006], s. 284-285; K. BACZKowsKi: Walka Jagiellonów z Maciejem Korwinem o koronę czeska w latach 1471-1479. Kraków 1980, s. $43-44$.

${ }_{31}$ Annales, lib. 12 [2005], s. 265; Roczniki, ks. 12 [2006], s. 277; Ratiborer Chronik..., s. 123.

32 Politische Correspondenz Breslaus..., s. 113, 122, nr 154, 159; Annales, lib. 12 [2005], s. 301; Roczniki, ks. 12 [2006], s. 316; J. SPERKA: Kazimierz Jagiellończyk wobec ksiażąt i księstw górnośląskich..., s. 111; TenżE: Tragiczne losy księcia rybnickiego Wacława III..., s. 261. Błędnie wymienia uczestników wyprawy J. Polak: Poczet panów..., s. 20.

${ }^{33}$ Annales, lib. 12 [2005], s. 301; Roczniki, ks. 12 [2006], s. 316. Rodzina Kropaczów w tym czasie dzieliła się już na dwie gałęzie: górnośląską (z Niewiadomia koło Rybnika) i morawską. Pieczętowali się herbem, który w błękitnej tarczy miał skrzyżowane trzy tyczki zakończone z jednej strony liliami - J. Pilnáček: Rody starého Slezska..., díl. 3, s. 831—833, tab. 45; C. BlažEK: Der abgestorbene Adel der preussischen Provinz Schlesien. Th. 1. Nürnberg 1887, s. 70, tab.45.

34 Annales, lib. 12 [2005], s. 301; Roczniki, ks. 12 [2006], s. 316; Politische Correspondenz Breslaus..., s. 113-114 (nr 154), s. 122 (nr 159); CDSil, Bd. 6, s. 96, nr 291. Szczegółowo o walkach pod Rybnikiem, Żorami i Pszczyną zob. J. SPERKA: Tragiczne losy księcia rybnickiego Wacława III..., s. 263; TenżE: Pszczyna i ziemia pszczyńska..., s. 97-98; TenżE: Do 1532 roku..., s. $153-154$. 
ocalił Wacława, ale pozbawiał go realnej władzy w dużej części księstwa. Jego warunki zakładały bowiem, że Żory (miasto i zamek) za zgodą obu stron konfliktu zostaną oddane w wierne ręce Jakubowi z Dębna, natomiast Rybnik - na tych samych zasadach — będzie przekazany Wacławowi Kropaczowi młodszemu z Niewiadomia. Ponadto ustalono, że gdyby Wacław zerwał rozejm, wówczas Żory (wraz z przynależną wsią Pielgrzymowice) zostaną wydane koalicji, natomiast ostatecznie jego sprawa miała trafić przed sąd rozjemczy króla polskiego ${ }^{35}$. Wejście w życie postanowień żorskich skutkowało tym, że w rękach Wacława rybnickiego została tylko Pszczyna z okręgiem ${ }^{36}$.

Warunki pokoju żorskiego nie zadowoliły jednak księcia ziębickiego Henryka Starszego z Podiebradów, który wiosną 1474 roku wszczął na nowo wojnę i obległ Rybnik. W tej sytuacji Wacław nieoczekiwanie zwrócił się o pomoc do króla Macieja Korwina. Władca przychylił się do jego prośby i z pomocą wysłał mu Jana Bielika z Kornic, który na czele dwutysięcznego oddziału uwolnił Rybnik. Kiedy jednak - zgodnie z umową - udał się pod Pszczynę, Wacław nie wpuścił go do miasta. Książę w międzyczasie zaczął bowiem żałować, że podporządkował się na powrót Korwinowi, i zmienił front. Zaopatrzył Rybnik i uciekł do Oświęcimia, gdzie poprosił o pomoc tym razem Jakuba z Dębna, starostę krakowskiego. Jednak w tym czasie Jan Bielik, po krótkim oblężeniu, zajął Pszczynę ${ }^{37}$. Po tych wydarzeniach król Maciej Korwin, rozzłoszczony na Wacława za wiarołomstwo, zaraz po zajęciu Pszczyny przez Bielika, zapewne jeszcze w kwietniu 1474 roku, uznał księcia za buntownika i odebrał mu ziemię pszczyńską. Rządy w niej oddał początkowo staroście Janowi Bielikowi, któremu za zasługi poczynił też zapisy na mieście Mikołowie ${ }^{38}$. Król unieważnił także wcześniejsze konfiskaty dóbr szlacheckich, których dopuścił się książę rybnicki, i zwrócił poszkodowanym majątki ${ }^{39}$. Kilka miesięcy później,

${ }^{35}$ CMV, s. 83-83v., 597-598, nr 49, 497 = CDSil, Bd. 6, s. 96-97, nr 292, 293 (regesty); Politische Correspondenz Breslaus..., s. 122, nr 159; Annales, lib. 12 [2005], s. 301; Roczniki, ks. 12 [2006], s. 316; R. Kubiciel: Ziemia pszczyńska..., s. 178; J. Sperka: Tragiczne losy księcia rybnickiego Wactawa III..., s. 263.

36 J. Sperka: Pszczyna i ziemia pszczyńska..., s. 98.

37 Annales, lib. 12 [2005], s. 330-331; Roczniki, ks. 12 [2006], s. 345-346.

38 Wzmiankują o tym dokumenty zamiany dóbr z 1475 r. między Hynkiem i Wiktorynem z Podiebradów - E. ZIvier: Geschichte..., s. 193, nr 15; Archiv český, čili staré písemné pámatky české i moravské. Díl. 15. Ed. J. KalouseK. Praha 1896, s. 259, nr 147. Obawiano się nawet, że Jan Bielik z Bogumina będzie chciał Mikołów zająć siłą. Jednak najpewniej już w roku następnym (1476) miasto znalazło się w rękach Jana z Wierzbna (Vrbna), który miał wtedy występować jako pan Mikołowa - K. Prus: Z przeszłości Mikołowa i jego okolicy. Mikołów 1996 (reprint na podstawie wyd. I - Mikołów 1932), s. 71 - co wskazywałoby, że miasto zostało podzastawione. Kiedy w 1480 r. Wiktoryn przeznaczył dobra pszczyńskie na ubezpieczenie posagu swojej córki, w stosownym dokumencie o sprawie Mikołowa już nic nie wspomniano - Listinár Těšínska..., nr 275.

${ }^{39} \mathrm{Na}$ ten temat zob. J. Rajman: Pogranicze..., s. 213; J. Sperka: Pszczyna i ziemia pszczyńska..., s. 98-99. 
16 grudnia 1474 roku (po podpisaniu 8 grudnia rozejmu z królem Kazimierzem Jagiellończykiem), król Maciej Korwin rozporządził ziemią pszczyńską, zastawiając ją za 20000 florenów swemu sojusznikowi księciu ziębickiemu Henrykowi (Hynkowi) Młodszemu z Podiebradów, synowi króla Jerzego z Podiebradów ${ }^{40}$.

Tymczasem Wacław rybnicki, po ucieczce ze swego księstwa, będąc w trudnej sytuacji finansowej, zdążył jeszcze zastawić Jakubowi z Dębna za 1830 florenów przynależny do okręgu pszczyńskiego klucz mysłowicki (miasto Mysłowice, wsie: Koziniec, Dziećkowice, Jaźwice, Brynów, Załęże, Szopienice) oraz dwie wsie: Roździeń i Bogucice. Ponadto (drugim dokumentem) za 1170 florenów oddał w zastaw sąsiadujące $\mathrm{z}$ kluczem mysłowickim wsie Brzezinkę i Brzęczkowice ${ }^{41}$. W sumie dług wobec kanclerza wynosił 3000 florenów. Książę szybko jednak oddawał należność. Jak wynika z dokumentu Dębińskiego z 14 sierpnia 1474 roku, w którym zeznał, że Wacław rybnicki zastawiał mu wspomniane dobra, książę spłacił mu już 1700 florenów i obiecywał, że kiedy tylko odda pozostałe 1300 florenów, to on zwróci mu zastawione dobra ${ }^{42}$. Zapewne w tym czasie (ale przed kwietniem 1474 roku) Wacław rybnicki zastawił też połowę klucza baborowskiego (połowa miasta Baborowa oraz wsie Boguchwałów i Kozłówki) Janowi Jičinskiemu ${ }^{43}$.

Wacław rybnicki jesienią 1474 roku wziął udział w polskiej wyprawie na Śląsk, w czasie której dostał się do niewoli. Więziony był najpierw w Ołomuńcu, a następnie oddano go w ręce księcia ziębickiego Henryka z Podiebradów, przez którego został wtrącony do lochu w kłodzkim zamku. Wolno-

${ }^{40}$ E. Zivier: Geschichte..., s. 187-188 = B. BELLERODE: Geschichtlische Untersuchungen über die Plessner Lehnsurkunden 1474-1500. In: TenżE: Beiträge zur Schlesischen Rechtsgeschichte. Heft 1. Breslau 1897, s. 24-28 = Listinár̆ Těšinska..., nr 256; R. Kubiciel: Ziemia pszczyńska..., s. 182-183; J. SPerka: Pszczyna i ziemia pszczyńska..., s. 98-99; TenżE: Tragiczne losy księcia rybnickiego Wacława III..., s. 265-266.

${ }^{41}$ CMV, s. 293v-294v, nr 244; CDSil, Bd. 6, s. 97, nr 294 (regest); Materiaty do dziejów wielkich Katowic (1299-1799). Wyd. L. MusıoŁ. Katowice 1936 (Pamiętnik Instytutu Śląskiego, T. 2), s. 51 (nr 6). R. Kubiciel (Ziemia pszczyńska..., s. 179) błędnie podaje, że Wacław jakoby sprzedał dobra mysłowickie, a także Brzezinkę i Brzęczkowice. Błędnie o zastawie pisze też J. Polak: Poczet panów..., s. 20.

${ }^{42}$ CDSil, Bd. 6, s. 97, nr 294, 295; J. SPERKa: Tragiczne losy księcia rybnickiego Wackawa III..., s. 264. Po przejęciu ziemi pszczyńskiej przez Kazimierza II cieszyńskiego dobra mysłowickie zostały przez niego zastawione Wacławowi Rudzkiemu (były w jego rękach w 1486 r.) - Materiaty do dziejów wielkich Katowic..., nr 7, s. 52-53. Później zostały wykupione przez księcia i wraz z całą ziemią pszczyńską sprzedane Aleksemu Turzonowi w $1517 \mathrm{r}$. (o sprzedaży zob. dalej).

${ }_{43}$ CDSil, Bd. 2, s. 213-214, nr 104 (w dokumencie jest informacja, że zastaw dokonany przez księcia Wacława potwierdził król Maciej Korwin, co wskazuje, że stało się to przed kwietniem 1474 r., kiedy to książę został uznany za buntownika). Jan Jičinski z czasem odstąpił jednak dobra Beneszowi z Boskovic i Černej Hory, który — nie chcąc ich użytkować w 1495 r. zwrócił je dominikankom raciborskim — tamże. 
ści już nie odzyskał, zmarł w Kłodzku w 1478 roku (po 23 stycznia, a przed 23 czerwca $^{44}$.

Henryk (Hynek) Młodszy z Podiebradów władał ziemią pszczyńską tylko kilka miesięcy, by 27 -28 czerwca 1475 roku wymienić się dobrami z bratem przyrodnim Wiktorynem, księciem opawskim. W zamian za ziemię pszczyńską i dopłatę 4000 florenów węgierskich przejął miasto Kolin nad Łabą w Cze$\mathrm{chach}^{45}$. Po tej transakcji Wiktoryn poszerzył swą tytulaturę o element pszczyński („dux Minsterbergensis, Oppaviensis, Blsstinensis”), a dobra pszczyńskie na dokumentach wychodzących z jego kancelarii zaczęto określać „księstwem pszczyńskim” (,in ducatu et confinio nostro Blsstinensi”) ${ }^{46}$. Jednak już 5 lat później, na początku 1480 roku, nowym właścicielem dóbr pszczyńskich został książę Kazimierz II cieszyński. Książę poślubił wtedy córkę Wiktoryna Jolantę, której posag wynoszący 8000 florenów ojciec 24 lutego 1480 roku zabezpieczył na tych dobrach ${ }^{47}$. Ponieważ książę opawski nie był w stanie wypłacić wspomnianej sumy, w 1484 roku zrezygnował na rzecz zięcia z ziemi pszczyńskiej, a król Maciej Korwin potwierdził to 27 sierpnia tego roku ${ }^{48}$. Z wszelkich roszczeń do ziemi pszczyńskiej na rzecz Kazimierza II zrezygnował też Jan IV Młodszy raciborski, który wcześniej taką rezygnację uzyskał od księżnej Małgorzaty oświęcimskiej, siostry Wacława III ${ }^{49}$. Kazimierz II cieszyński po przejęciu rządów w dobrach pszczyńskich — wzorem swego poprzednika - dołączył do swojej tytulatury określenie „pan pszczyński” (pán

${ }^{44}$ Ratiborer Chronik..., s. 123; Annales, lib. 12 [2005], s. 356; Roczniki, ks. 12 [2006], s. 372; J. SPerka: Tragiczne losy księcia rybnickiego Wacława III..., s. 266.

${ }^{45}$ E. Zivier: Geschichte..., s. 190-198, nr 14-16; B. Bellerode: Geschichtlische..., s. 28-36; R. Kubiciel: Ziemia pszczyńska..., s. 184-186; J. Sperka: Pszczyna i ziemia pszczyńska..., s. 99-100.

${ }^{46}$ E. ZIVIER: Geschichte..., s. 123-124; J. Sperka: Pszczyna i ziemia pszczyńska..., s. 100, 110. R. Kubiciel (Ziemia pszczyńska..., s. 186-187) nietrafnie więc pisze, że na dokumentach Wiktora nie używano nazwy „księstwo pszczyńskie”.

${ }^{47}$ Listinár̆ Těšinska..., nr 275. Błędnie sprawę przejęcia dóbr pszczyńskich przez Kazimierza II przedstawia I. PANIC (Śląsk Cieszyński..., s. 183), sugerując, że stało się to na mocy nadania królewskiego w 1498 r. Jednak we wcześniejszej pracy: Żory pod rząami Przemyślidów..., s. 96-98, problem przedstawił w miarę poprawnie.

${ }^{48}$ H.W.F. SCHAEFFER: Kronika wolnego państwa stanowego a od 1827 r. księstwa pszczyńskiego. Cz. 1-2. Wyd. B. Spyra. Pszczyna 1997, s. 14. Informacje te potwierdza Kazimierz II w liście z 23 kwietnia 1498 r., który przesłał do Wrocławia na zjazd stanów śląskich (,,[...] herzog Victorino, der dann so sorter herczog Kazimiro sohls umb ettlich summa geldes verpfendt unad darnach gar mit einander herczog Kazimiro vorschribt und abgetreten") - E. ZIvier: Geschichte..., s. 216, nr 23. Podobnie przedstawia to dokument Władysława Jagiellończyka z 1500 r., zmieniający stan prawny dóbr pszczyńskich z lennego na dziedziczny; tam podane jest, że Wiktor odstąpił dobra Kazimierzowi („témuž Kazimírovi postúpil”) - Archiv český, čili staré pisemné pámatky české i moravské. Díl. 18. Ed. J. KalouseK. Praha 1900, s. 26; E. Zivier: Geschichte..., s. 222, nr 24.

49 E. Zivier: Geschichte..., s. 214-222, nr 23; B. Bellerode: Geschichtlische..., s. $60-$ 67; A. Weltzel: Historia miasta Żory..., s. 56; szerzej o tym zob. dalej. 
blšč́nský), chociaż kancelaria książęca używała go sporadycznie i właściwie tylko na niektórych dokumentach dotyczących tych dóbr ${ }^{50}$.

Po uwięzieniu Wacława III w Kłodzku sprawą sukcesji w księstwie rybnickim zainteresował się po pewnym czasie król Władysław Jagiellończyk, dostrzegł bowiem możliwość osłabienia pozycji króla Macieja Korwina, a zarazem pozyskania sojuszników. W dokumencie z 26 stycznia 1477 roku, wystawionym dla Henryka Starszego z Podiebradów, księcia ziębickiego, Jagiellończyk uznał księcia rybnickiego za zdrajcę, ponieważ ten przystał do jego nieprzyjaciół, a dodatkowo najeżdżał sąsiadów. Jednocześnie król wyraził zgodę na umowę, na mocy której uwięziony Wacław zrzekał się swojego księstwa na rzecz wspomnianego Henryka ziębickiego ${ }^{51}$. To niewątpliwie wymuszone ustępstwo otwarło Podiebradom drogę do ostatecznego zalegalizowania posiadania części księstwa rybnickiego, gdyż dobra pszczyńskie, trzymane do tej pory dzięki łasce króla Macieja, uzyskiwały sankcję drugiego króla Czech, Władysława. W dniu 23 czerwca 1478 roku Władysław Jagiellończyk udzielił Henrykowi za wierną służbę — jak zaznaczył w dokumencie — inwestytury na księstwo po zmarłym Wacławie, obejmujące Pszczynę (zamek i miasto), Żory (miasto) oraz Rybnik (zamek i miasteczko) ${ }^{52}$. Jednak Henryk ziębicki prawa uzyskane od króla — dwoma aktami: z 14 lipca 1477 roku i 23 stycznia 1478 roku - przekazał swemu bratu Wiktorynowi, który nie był sojusznikiem Jagiellończyka ${ }^{53}$.

Pokój w Ołomuńcu z lipca 1479 roku, kończący rywalizację o tron czeski między Władysławem Jagiellończykiem i Maciejem Korwinem, pozostawił Śląsk pod panowaniem tego drugiego. To z kolei ugruntowało zmiany, które za sprawą Korwina zaszły tam wcześniej, w tym w księstwie rybnickim, gdzie ziemia (okręg) pszczyńska — jak wspomniałem — w wyniku konfiskaty królewskiej znalazła się w rękach Podiebradów. Pozostała część księstwa rybnickiego nie została objęta konfiskatą, a więc Żory i Rybnik od 1473 roku pozostawały w rękach zastawników. To pierwsze miasto dzierżył Jakub z Dębna, to drugie Wacław Kropacz z Niewiadomia ${ }^{54}$. Po śmierci księcia Wacława III (1478) terytoria te stały się polem rywalizacji między jego spadkobiercami. Mimo że grono najbliższych krewnych zmarłego było spore, to batalia

50 J. Sperka: Pszczyna i ziemia pszczyńska..., s. 102-104.

${ }^{51}$ Archiv český..., díl. 18, s. 23; E. Zivier: Geschichte..., s. 198-199, nr 17; Listinár Těšinska..., nr 266; J. SPERKA: Tragiczne losy księcia rybnickiego Wacława III..., s. 269-270.

${ }_{52}$ Archiv český..., díl. 18, s. 25-26; E. Zivier: Geschichte..., s. 203-205 (nr 19); B. Bellerode: Geschichtlische..., s. 50-53.

${ }_{53}$ Archiv český..., díl. 18, s. 25; E. Zivier: Geschichte..., s. 201-202 (nr 18), 206-207 (nr 20); B. Bellerode: Geschichtlische..., s. 54-56; R. KuBiciel: Ziemia pszczyńska..., s. 190.

54 J. Sperka: Pszczyna i ziemia pszczyńska..., s. 99, 142, przyp. 150. Błędnie podaje T. KREJČ́́ (Václav (okolo 1440 \% 1478). V: Biografický slovník Slezska..., Č. 4, s. 106), że część raciborską, która pozostała po Wacławie (Rybnik i Żory), miał jakoby przejąć król Maciej Korwin. 
o przejęcie Rybnika i Żor rozegrała się między jego przyrodnią siostrą Małgorzatą (Machną), żoną Kazimierza oświęcimsko-zatorskiego (z jednej strony), a kuzynem Janem IV Młodszym, księciem raciborskim, i później żoną tegoż, Magdaleną opolską (z drugiej strony).

W 1478 roku, wkrótce po śmierci Wacława III, Jan IV raciborski wykupił Żory od Jakuba z Dębna za 1400 florenów $^{55}$. Na tę transakcję wyraziła zgodę mająca prawo do spadku siostra Wacława III - Małgorzata, co potwierdziła przed starostą Górnego Śląska Janem Bielikiem z Kornic 12 sierpnia 1482 roku w Hulczynie, a król Maciej Korwin zatwierdził dokumentem wystawionym w Budzie 27 czerwca 1483 roku $^{56}$. Jednak po pewnym czasie Małgorzata zmieniła zdanie i 2 marca 1484 roku ponownie przed starostą Bielikiem, w obecności swego męża, zeznała, że owszem - potwierdza to, z czego wcześniej zrezygnowała, czyli z prawa do spadku po ojcu i matce na rzecz Jana raciborskiego, jednakże nie dała temuż księciu pełnomocnictwa, aby wykazywać się przed królem, jakoby ona nie miała żadnych praw do Żor. Prosiła zatem o wystawienie takiego dokumentu dla księcia raciborskiego, co na jej prośbę starosta uczynił. Skutkiem tego na spornym obszarze nadal funkcjonowała dwuwładza, a dobitnie o tym świadczy dokument z 24 kwietnia 1484 roku, wystawiony wspólnie przez Jana raciborskiego i Kazimierza oświęcimskiego (tytułującego się panem Żor), którym rozstrzygali spór między braćmi Maciejem i Piotrem Osińskimi z Żytnej a mieszczanami Żor o granice między Baranowicami (gdzie wspomniani bracia założyli staw) a Kleszczowem ${ }^{57}$. Nie będąc jednak w stanie wykupić miasta $\mathrm{z}$ rąk księcia raciborskiego, księżna Małgorzata wystawiła 2 grudnia 1486 roku w Żorach dokument, w którym oświadczyła, że za radą męża doszło w Raciborzu do podpisania z księciem Janem raciborskim aktu sprzedaży Żor ${ }^{58}$. Rok później, 5 października 1487 roku, księżna Małgorzata i książę Kazimierz, mając na uwadze wyjątkową miłość do księcia raciborskiego, zobowiązali się po swojej śmierci przepisać mu wszystkie swoje ziemie i spadek; gdyby jednak doczekali się dzieci (co się jednak nie stało), układ stawał się nieważny ${ }^{59}$.

${ }^{55}$ Ratiborer Chronik..., s. 123; R. KuBICIEL: Ziemia pszczyńska..., s. 185. Bałamutnie na ten temat I. PANIC (Żory pod rzadami Przemyślidów..., s. 98-99).

56 A. Weltzel: Historia miasta Żory..., s. 51.

57 Tamże, s. 53-54.

${ }^{58}$ Tamże, s. 51. Pieniądze ze sprzedaży książę Kazimierz przeznaczył wkrótce na krótkotrwałą pożyczkę dla króla polskiego Kazimierza Jagiellończyka. 1 maja 1488 r. na sejmie w Piotrkowie król potwierdził, że pożyczył od księcia 2000 florenów z obowiązkiem spłaty do św. Jana Chrzciciela (24 czerwca) — KDP, T. 4, nr 97 = Listinár̆ Těšínska ..., nr 311.

${ }^{59} \mathrm{CDSil}$, Bd. 6, s. 127, nr 379. Błędnie zatem przedstawiają sprawę przejęcia Żor przez Jana raciborskiego: I. PANIC (Żory pod rzadami Przemyślidów..., s. 99), który datował to na 1483 r., N. Mika (Przemyślidzi opawsko-raciborscy. Blaski i cienie panowania. „Ziemia Raciborska. Rocznik historyczno-przyrodniczy” 2006, 9 (69), s. 53), datujący to na 1480 r., oraz T. GóreCKi i M. WieczoreK (Książęta Górnego Śląska..., s. 154), przypuszczający, że Żory 
Jeśli chodzi o Rybnik, to ten - w bliżej nam nieznanych okolicznościach po śmierci Wacława — również przypadł Janowi IV Młodszemu raciborskiemu w wyniku układów z Małgorzatą oświęcimską, jak świadczą o tym późniejsze źródła ${ }^{60}$. Prawa zwierzchnie do miasta posiadał już w 1483 roku, gdyż wtedy wydał przywilej, którym regulował sprawy dziedziczenia majątku mieszczan rybnickich $^{61}$. Jednak miasto z przynależnym okręgiem nadal było w zastawie u Kropaczów, a księciu do śmierci w 1493 roku (14 kwietnia) nie udało się go wykupić ${ }^{62}$. Nic też w kwestii wykupu miasta nie zmieniło się w roku następnym, co potwierdza układ zawarty 7 września 1495 roku w Krakowie między księżną Magdaleną, wdową po Janie IV Młodszym raciborskim, a księżną Małgorzatą, wdową po Kazimierzu oświęcimsko-zatorskim. Krakowskie porozumienie regulujące umowę między mężami księżnych — zakładało, że Magdalena ma wypłacić Małgorzacie do 11 listopada tego roku 100 florenów wcześniejszych zobowiązań. Ponadto, jeśli Magdalena (lub jej spadkobiercy) wykupi Rybnik zamek i miasto $\mathrm{z}$ okręgiem - to w ciągu 4 lat wypłaci Małgorzacie kolejne 100 florenów. Ta z kolei będzie musiała wystawić pokwitowanie odbioru, z dopiskiem, że otrzymała wystarczającą kwotę za swoją część spadkową, i nie będzie już wysuwała roszczeń w stosunku do Żor i Rybnika ${ }^{63}$. Jednak w 1496 roku Rybnik nadal był w rękach Wacława Kropacza ${ }^{64}$. Natomiast nie jest wykluczone, że Magdalena jeszcze w tym roku wykupiła miasto, skoro 29 sierpnia 1496 roku burmistrz i rajcy rybniccy ręczyli za księżną — wraz z burmistrzami i rajcami raciborskimi oraz żorskimi, a także z 15 przedstawicielami szlachty księstwa — że ta odda dług w kwocie 1200 florenów księciu Mikołajowi opolskiemu do dnia św. Bartłomieja (23 sierpnia) przyszłego roku ${ }^{65}$. Niewątpliwie jednak dobra rybnickie zostały wykupione $\mathrm{z}$ rąk Korpaczów przed 1508 rokiem, wtedy bowiem książę Walentyn Garbaty, ostatni z Przemyślidów

wróciły do księstwa raciborskiego dopiero po śmierci Korwina (sugerujący też, że rzekomo w 1487 r. miasto stało się częścią posagu Blanki Sforzy zapisanego przez Jana Korwina — na ten temat zob. dalej).

${ }^{60}$ W literaturze przedmiotu (F. IDzIKowski: Geschichte Stadt..., s. 46; A. Trunkhardt: Kronika Rybnicka..., s. 31; N. MıкA: Dzieje ziemi raciborskiej..., s. 41; T. GóReCKI, M. WIECzoreK: Ksiązęta Górnego Śląska..., s. 154) pojawiają się sugestie, że w latach 1478-1483 Rybnik był w rękach brata Wacława III, Jana karniowskiego, i dopiero po jego śmierci miał go przejąć Jan IV Młodszy raciborski. Jednak żadne źródło nie daje podstaw do takich wniosków — zob. na ten temat: J. SPERKA: Do 1532 roku..., s. 158-160.

${ }^{61}$ F. Idzikowski: Geschichte Stadt..., s. 54-55; A. Trunkhardt: Kronika Rybnicka..., s. $36-37$.

${ }^{62}$ W 1494 r. Kropacz z Niewiadomia, tytułując się panem na Rybniku, rozporządzał folwarkiem w Biertułtowach wchodzących w skład dóbr rybnickich — F. IDZIKowsKI: Geschichte Stadt..., s. 46; A. Trunkhardt: Kronika Rybnicka..., s. 31; J. Sperka: Do 1532 roku..., s. 160.

${ }^{63}$ CMV, s. 102-103v., nr 66 = CDSil, Bd. 6, s. 140, nr 424 (regest); A. Weltzel: Historia miasta Żory..., s. 55; J. Sperka: Tragiczne losy księcia rybnickiego Wacława III..., s. 269.

${ }^{64}$ J. PilnáČeK: Rody starého Slezska..., díl. 3, s. 832.

${ }^{65}$ CDSil, Bd. 6, s. 142, nr 428. 
raciborskich, obdarzył Rybnik przywilejem ${ }^{66}$, ale jeszcze $\mathrm{w}$ tym roku oddał miasto wraz $\mathrm{z}$ okręgiem w zastaw Zygmuntowi Wyszkocie z Wodnik (zm. przed 1525 rokiem), kanclerzowi księstwa raciborskiego (1506-1522) ${ }^{67}$.

Księżna Małgorzata oświęcimsko-zatorska wkrótce po przegranej batalii o Żory i Rybnik podjęła próbę odebrania ziemi pszczyńskiej księciu Kazimierzowi cieszyńskiemu. Wniosła więc pisemną skargę przeciw niemu do obradujących 6 stycznia 1498 roku we Wrocławiu stanów śląskich. Oskarżyła księcia o zajęcie miasta i zamku pszczyńskiego, argumentując, że dobra te należą się jej jako część spadku po bracie. Kazimierz jednak szybko zaczął przeciwdziałać. Najpierw wystarał się u króla Władysława Jagiellończyka o dokument potwierdzający prawo posiadania tych dóbr. W wystawionym 23 lutego 1498 roku akcie monarcha przypomniał, że dobra pszczyńskie król Maciej Korwin odebrał Wacławowi i za pieniądze przekazał Hynkowi z Podiebradów. Później otrzymał je Henryk ziębicki, a następnie na takich samych prawach nadał Kazimierzowi i jego potomkom ${ }^{68}$. Mając wsparcie królewskie, książę cieszyński odpowiedział na zarzuty Machny w liście z 23 kwietnia 1498 roku skierowanym do stanów śląskich. Dowodził w nim ze szczegółami, że rzeczywiście Wacław niegdyś posiadał Pszczynę, ale odebrał mu ją król Maciej Korwin. Później książę raciborski Jan IV Młodszy (krewny Wacława III), opiekun Małgorzaty, nabył dla niej Żory jako odszkodowanie, na co księżna wyraziła zgodę, a co książę cieszyński poświadczył trzema dokumentami (króla Macieja Korwina, biskupa wrocławskiego Jana Rotha i starosty Śląska Jana Bielika z Kornic). Dobra pszczyńskie natomiast - pisał dalej Kazimierz II cieszyński - król Maciej Korwin nadał Hynkowi z Podiebradów, które ten wkrótce zamienił z bratem Wiktorynem na Kolin. Z kolei Wiktoryn oddał je Kazimierzowi II cieszyńskiemu w zastaw, a potem odstąpił mu je całkowicie. Małgorzata zrezygnowała na rzecz księcia Jana IV Młodszego raciborskiego z wszelkich praw do Pszczyny, który odstąpił je następnie Kazimierzowi. W odpowiedzi na ten ostatni argument księżna Małgorzata zaprzeczyła, jakoby wyraziła na to zgodę ${ }^{69}$.

Księżna Małgorzata, rozpoczynając spór z Kazimierzem II cieszyńskim o dobra pszczyńskie, miała już zaplanowane dalsze kroki. Precyzowała to umowa zawarta 25 września 1498 roku w Krakowie przed sądem grodzkim z Pawłem Czarnym z Witowic, żupnikiem krakowskim. Gdyby księżnej udało się uzyskać księstwo pszczyńskie (Ducatum Plsczinensi) drogą prawną lub za

${ }^{66}$ Było to potwierdzenie przywileju wydanego przez jego ojca Jana IV w 1483 r., a dotyczyło przejmowania przez miasto dóbr po zmarłych bezpotomnie mieszczanach - F. IDzıKowSKI: Geschichte Stadt..., s. 54-55; A. TRUNKhARdT: Kronika Rybnicka..., s. 36-37.

${ }^{67}$ J. Pilnáček: Rody starého Slezska..., díl. 5, s. 1348; J. SPERka: Do 1532 roku..., s. 162.

${ }^{6}$ Archiv český..., díl. 18, s. 21-22, nr 11.

${ }^{69}$ E. Zivier: Geschichte..., s. 214-222, nr 23; B. Bellerode: Geschichtlische..., s. 60-67; LBS, T. 2, s. 401, nr 33 (regest); A. Weltzel: Historia miasta Żory..., s. 56. 
pomocą ugody z księciem Kazimierzem, wówczas zobowiązywała się wymienić zamek i miasto Pszczynę z miasteczkami: Mikołów, Bieruń i Mysłowice, wraz ze wszystkimi przynależnymi doń wsiami, na dobra dziedziczne Pawła, na które składały się leżące w ziemi krakowskiej: Witowice, Gotprzydowice, Szarkówka, Topola i Dąbrówka, oraz te, które miał w zastawie: Charsznicę, Szreniawę, Adamowice i Wierzchowisko (też ziemia krakowska) ${ }^{70}$.

Plany księżnej pokrzyżował jednak Kazimierz II cieszyński, który na kolejnym zjeździe stanów śląskich we Wrocławiu 21 stycznia 1499 roku postarał się o nowe dowody w sprawie. Przedstawił mianowicie dokument, przesłany przez posłańca z Raciborza, wedle którego księżna odstąpiła jednak od swoich roszczeń wobec Pszczyny na rzecz księcia Jana IV raciborskiego, a uczyniła to przed starostą Górnego Śląska Janem Bielikiem. Chociaż księżna Małgorzata żądała nowego terminu rozprawy, to stany odrzuciły jej pretensje. Trzy dni później, 24 stycznia 1499 roku, biskup wrocławski Jan Roth i książę ziębicki Karol z Podiebradów wystawili dokument z wyrokiem stanów, który na prośbę Kazimierza II cieszyńskiego król Władysław Jagiellończyk potwierdził 1 maja tegoż roku ${ }^{71}$. Rok później, 28 sierpnia 1500 roku, monarcha kolejnym dokumentem uwolnił dobra pszczyńskie (panstwý Blasstinske) od wszelkich ciężarów lennych, czyniąc z nich alodium, czyli dobra dziedziczne z prawem swobodnego rozporządzania ${ }^{72}$. Kilkanaście lat później Kazimierz II cieszyński popadł jednak w kłopoty finansowe, co spowodowało, że 21 lutego 1517 roku sprzedał dobra pszczyńskie Aleksemu Turzonowi za 40000 florenów ${ }^{73}$. Dwa lata później — 26 maja 1519 roku — król Ludwik Jagiellończyk potwierdził transakcję, uznając Aleksego Turzona za nowego właściciela dóbr pszczyńskich ${ }^{74}$.

W zabiegi o schedę po Wacławie III nie włączył się jego brat — też przegrany i upokorzony przez króla Korwina — Jan Starszy karniowski. Podległe mu zamki: Vartnov, Fürstenwalde, Lobenstein (Cvilín) oraz Plšti (k. Opawy), zostały zniszczone w czasie ofensywy prowadzonej w końcu sierpnia 1474 roku

${ }^{70}$ SPPP II, nr 4509; E. ZIVIER: Geschichte..., s. 212-214, nr 22; SHGKr, Cz. 1, s. 4, 523, 819.

${ }^{71}$ E. Zivier: Geschichte..., s. 214-222, nr 23; B. Bellerode: Geschichtlische..., s. 60 67; LBS, T. 2, s. 402, nr 34.

72 AP Katowice, Oddział w Pszczynie, sygn. II-34; Archiv český..., díl. 18, s. 26-27; E. Zivier: Geschichte..., s. 222-223, nr 24; R. KuBICIEL: Ziemia pszczyńska..., s. 194.

73 AP Katowice, Oddział w Pszczynie, sygn. II-38; B. Bellerode: Urkunden über die Besitz- und Rechts-Verhältnisse der Herrschaft Pless 1517-1854. In: TenżE: Beiträge zur Schlesischen Rechtsgeschichte. Heft 2. Breslau 1898, s. 92-100; Listinár̆ Těšinska. Codex diplomaticus ducatus tesinensis. Sv. 4: 1495-1526. Zprac. E. NĚMEC. Český Těšín 1961, nr 405; L. Musiol: Dokument sprzedaży Księstwa Pszczyńskiego z dn. 21 lutego 1517 r. „Roczniki Towarzystwa Przyjaciół Nauk na Śląsku” 1930, T. 2, s. 235-239; Tenże: Pszczyna ..., s. 44-45; D. PINDur: Książe czasów przełomu. Kazimierz II cieszyński (1459-1528) i jego władztwo. Wrocław 2010, s. 121-123; J. Sperka: Pszczyna i ziemia pszczyńska..., s. 105-106.

74 B. Bellerode: Urkunden..., s. 100-104; Listinář Těšinska..., Sv. 4, nr 414 (regest); LBS, T. 2, s. 408, nr 46 (regest). 
na Morawach przez wojska Macieja ${ }^{75}$. W trakcie walk książę Jan 30 sierpnia został wzięty do niewoli przez Wiktoryna opawskiego, który oddał go królowi Maciejowi Korwinowi oblegającemu pobliskie Albrechcice. Monarcha ostatecznie uwolnił go, ale pod warunkiem, że odda mu Karniów i w ciągu 8 dni stawi się we Wrocławiu przed sądem królewskim. Przejęte miasto przekazał następnie w wierne ręce Janowi Bielikowi z Kornic, Mikołajowi Hrdy z Kłokocina i Urbanowi, mieszczaninowi karniowskiemu ${ }^{76}$. Zgodnie z umową książę Jan Starszy stawił się we Wrocławiu, gdzie od połowy września przebywał $\mathrm{kró}^{177}$. Jednak jeszcze przed jesienną polską wyprawą na Wrocław - jak podaje Kronika raciborska - Maciej Korwin, w zamian za wolność, odebrał mu Karniów z zamkiem Lobenstein, Baborów (faktycznie tylko połowę) i Brun$\operatorname{tal}^{78}$. Te ostatnie dobra (zamek, miasto i $10 \mathrm{wsi}$ ) w niedługi czas później (ale jeszcze w latach 70.) król zastawił panom z Wierzbna (Vbrna), Janowi i Stefanowi ${ }^{79}$. Księciu Janowi Starszemu został tylko Wodzisław z okręgiem, gdzie rezydował do śmierci w 1483 roku. Książę nie był żonaty, nie pozostawił po sobie potomstwa, a w tej sytuacji to król przejął obumarłe lenno ${ }^{80}$. W 1487 roku księstwo wodzisławskie z zameczkiem (,ducatus Vuladislaviensis cum fortlalicio") stało się częścią zabezpieczenia posagu (wraz z innymi księstwami), który gwarantował Jan Korwin, syn króla węgierskiego Macieja Korwina, w czasie zaślubin per procura 25 listopada tego roku w Mediolanie z księżną Blanką Marią Sforzą (małżeństwo nie zostało jednak dopełnione) ${ }^{81}$. Dobra

75 T. KrejČíK: Jan (kolem r. 1435 † 1483). V: Biografický slovník Slezska..., Č. 4, s. 10; A. TuReK, L. JISL: Ostravsko za česko-uherské válký ve světle písmných pramenů i archeologických nálezü. „Časopis Slezského muzea. Serie B — védy historické” 1953, 3, s. 8-13; P. Kouřil, M. Wihoda, D. Prix: Hrady českého Slezska..., s. 40-41, 151, 354, 523-525; A. Kalous: Matyáš Korvín..., s. 151.

${ }^{76}$ Archiv český..., díl. 4, nr 16, s. 338 = LBS, T. 2, s. 511, nr 55 (regest).

77 R. Honváth: Itineraria regis Matthiae Corvini et regine Beatricis de Aragonia (1458[1476]-1490). Budapest 2011, s. 102.

78 Ratiborer Chronik..., s. 123.

${ }^{79}$ LBS, T. 2, s. 526-527, nr 73 (tu w dokumencie z 1496 r. informacja, że Wierzbińscy posiadają dobra w zastawie od króla Macieja Korwina. Nie ma jednak uzasadnienia, aby na podstawie tego dokumentu - jak czynią P. KouřIL, M. Winoda, D. Prix: Hrady českého Slezska..., s. 29 - datować zastaw tych dóbr na 1474 r.). Zob. też: J. StiBor: Bruntálští z Vrbna..., s. 29; T. Jurek: Panowie z Wierzbnej. Studium genealogiczne. Kraków 2006, s. 61-63.

${ }^{80}$ Ratiborer Chronik..., s. 123-124. Brak podstaw źródłowych, aby uznać, jak przyjmują T. GóReCKi i M. WieCzoreK (Książęta Górnego Śląska..., s. 150), że książę zmarł 14 kwietnia.

${ }^{81}$ LBS, T. 1, s. 33, nr 19 (regest). O pertraktacjach małżeńskich zob. A. KaLous: Matyáš Korvín..., s. 299-300. Z księstw śląskich, które posiadał Jan Korwin, w skład przyszłego posagu weszły też: opawskie, głubczyckie, toszeckie, bytomskie i kozielskie. Nieporozumieniem jest natomiast pojawiająca się w literaturze przedmiotu (A. Weltzel: Historia miasta Żory..., s. 52; T. GóreCKI, M. WieczoreK: Ksiązę̧ta Górnego Śląska..., s. 154) informacja, że w skład posagu weszło również księstwo raciborskie albo Żory. Wynika to z błędnych odczytu i identyfikacji — przez wydawców LBS, T. 1, s. 33 - nazwy księstwa kozielskiego (,ducatus Rosboniensis cum castro Rozle") oraz utożsamienia go z księstwem raciborskim (rzekomo 
wodzisławskie w następnych latach zarządzane były przez królewskich starostów; w 1492 roku był nim Jan Milotha ze Sławikowa ${ }^{82}$. Natomiast w 1502 roku (12 marca) król Władysław Jagiellończyk nadał prawem wieczystym Wodzisław z przynależnościami za zasługi wielkiemu kanclerzowi Królestwa Czech Janowi z Šelmberka (zm. 1508) ${ }^{83}$.

$\mathrm{Z}$ roszczeniami do spadku po Wacławie rybnickim początkowo nie występowała jego rodzona siostra Barbara, żona Janusza IV oświęcimskiego. Może dlatego, że jej mąż też został bardzo stanowczo potraktowany przez króla Macieja Korwina, który w 1475 roku, oskarżając go o rozbójnictwo, pozbawił go posiadanej połowy Gliwic i uwięził w zamku Lobenstein ${ }^{84}$. Dopiero po śmierci króla (6 kwietnia 1490 roku) księżna wysunęła pretensje do schedy, ale tylko po Janie III Starszym i w dodatku jedynie do Karniowa. Jej roszczenia początkowo zostały uznane przez społeczność miasta, o czym świadczy jej dokument (wystawiony razem z mężem, księciem Januszem) z 12 sierpnia 1491 roku, którym jako pani na Karniowie potwierdziła prawa i przywileje miasta $^{85}$. Natomiast nowy król, Władysław Jagiellończyk, inaczej podszedł do sprawy, uznał bowiem księstwo karniowskie za obumarłe lenno i nadał je 3 października 1493 roku dziedzicznie za zasługi Janowi z Šelmberka, wielkiemu kanclerzowi Korony Czeskiej ${ }^{86}$. Księżna Barbara już jednak od roku była związana rodzinnie z obdarowanym: jej córka Helena w 1492 roku wyszła bowiem za mąż za Jerzego z Šelmberka (zm. 1529), syna kanclerza. W efekcie przez następne kilkanaście lat Barbara rządziła księstwem wspólnie ze swoim zięciem $^{87}$. W 1496 roku (18 czerwca) przedłużyła, na podstawie przedłożonego

Ratsboriensis $=$ Ratiobor). W tym miejscu należy podkreślić, że Jan Korwin ani do księstwa raciborskiego, ani do Żor nie miał żadnych praw, a posag został zapisany na księstwach, które aktualnie posiadał. Sprawa jednak stała się bezprzedmiotowa, ponieważ małżeństwo nie zostało dopełnione.

${ }^{82}$ CDSil, Bd. 6, s. 135, nr 406.

${ }^{83}$ Archiv český..., díl. 18, s. 3-4.

${ }^{84}$ Annales, lib. 12 [2005], s. 355-356; Roczniki, ks. 12 [2006], s. 371-372; Ratiborer Chronik..., s. 123; J. RaJman: Jan (Janusz) IV. W: Piastowie. Leksykon biograficzny. Red. S. Szczur, K. OżóG. Kraków 1999, s. 812. W 1483 r. księżna Barbara uzyskała od Kazimierza II cieszyńskiego zapis 300 grzywien na Pszczynie. Kwota była pozostałą częścią długu, który należny był jej mężowi Januszowi oświęcimskiemu od Przemka cieszyńskiego (wcześniej wypłacono księciu 400 grzywien), a którego zobowiązania przejął wspomniany Kazimierz - CDSil, Bd. 6, s. 116, nr 350.

${ }^{85}$ F. Kоретzку: Zur Geschichte und Genealogie der Přemyslidischen..., s. 84; G. Biermann: Geschichte der Herzogthümer Troppau..., s. 229; T. Kresčík: Vaclav..., s. 106; E. ŠEFČ́́k: Barbara (ok. 1445-1510/1511). W: Ksiązęta i księżne Górnego Śląska..., s. 18; P. Kouřil, M. Winoda, D. Prix: Hrady českého Slezska..., s. 525.

86 J. Stibor: Bruntálští z Vrbna..., s. 30; P. KouřIl, M. Wihoda, D. Prix: Hrady českého Slezska..., s. 525.

${ }^{87}$ R. Fukala: Jiři ze Šelmberka. V: Biografický slovnik Slezska a severni Moravy. Č. 11. Ostrava 1998, s. 136. 
jej dokumentu króla Korwina, na dalsze 10 lat zastaw dóbr bruntalskich braciom Bernardowi, Hynkowi i Mikołajowi z Wierzbna (Vbrna), którzy dzierżyli je za 3000 florenów $^{88}$. Ponieważ sumy zastawne nie zostały spłacone, po upływie terminu Barbara i Jerzy z Šelmberka oddali Wierzbińskim dobra. W ich skład wchodziły: miasto i zamek Bruntal z mytem i młynami, wsie: Górne i Dolne Wilgruby (dziś: Václavov), Lichtward (dziś: Světlá), Stare Město, Wiederfle (dziś: Malá Věska), Nová Věska, wsie opuszczone: Zarnica, Jelena, i Loučka ${ }^{89}$. W styczniu 1498 roku księżna wybrała się do Wrocławia, aby złożyć hołd królowi Władysławowi Jagiellończykowi. Nie wiemy jednak, jak sprawa się potoczyła dalej, ponieważ na dokumencie homagialnym książąt śląskich z 10 stycznia tego roku nie została wymieniona ${ }^{90}$. Barbara zmarła po 11 kwietnia 1511 roku, a przed 16 czerwca 1511 roku, natomiast księstwo karniowskie jej wnukowie, Jerzy, Jan i Jarosław Šelmberkowie, jeszcze za życia matki - Heleny, sprzedali w 1524 roku (27 maja) margrabiemu brandenburskiemu Jerzemu Hohenzollernowi ${ }^{91}$.

Księstwo karniowsko-rybnickie, powstałe w 1437 roku w wyniku podziału schedy po księciu raciborskim Janie II Żelaznym, a przypadłe jego starszemu synowi Mikołajowi, zachowało integralność terytorialną tylko do 1465/1466 roku. Wtedy bowiem Jan III Starszy i Wacław III (synowie Mikołaja) przeprowadzili podział, którego skutkiem było powstanie księstwa karniowskiego (z Karniowem, Bruntalem i Wodzisławiem) i rybnickiego (z Rybnikiem, Żorami, Pszczyną). Na dalsze losy tych niewielkich księstw niewątpliwie przemożny wpływ wywarła wojna o koronę czeską, która toczyła się w latach 70 . między Jagiellonami i Maciejem Korwinem. Zmusiła ona braci do lawirowania między stronami konfliktu, co wkrótce spowodowało odrzucenie i oskarżenie o zdradę przez jednych i drugich. W przypadku jednak Wacława III nie mniej zaszkodziło mu awanturnicze zachowanie w stosunku do swoich sąsiadów, książąt śląskich, z którymi był permanentnie skłócony i ciągle na stopie wojennej. Nierozważne rządy Wacława, a potem bezpotomna śmierć (1478), przyniosły koniec istnienia księstwa rybnickiego, którego część pszczyńską

${ }^{88}$ LBS, T. 2, s. 527-528, nr 73.

89 J. STiBor: Bruntálští z Vrbna..., s. 30.

90 Silesiacarum Rerum Scriptores. Bd. 1. Hrsg. F. SommersBerg. Lipsiae 1729, s. 1062 1063, nr 178, 180; LBS, T. 2, s. 528, nr 74 (regest) = Katalog średniowiecznych dokumentów..., nr 16669, 16706.

${ }_{91}$ Opavský Listinár̆. Díl. 5. Ed. F. Šıgut. Opava 1996, nr 124 (ostatni znany dokument księżnej Barbary dotyczący sprzedaży przez nią na wyderkaf 11 florenów z czynszu Karniowa za 130 florenów altaryście Marcinowi Faberowi i jego matce Katarzynie); K. JASIŃsKi: Rodowód Piastów ślaskich..., s. 649—650; F. СносноLATÝ: Genealogie opavských Přemyslovců..., s. 151; R. FuKala: Jiři ze Šelmberka..., s. 137. 
skonfiskował król Maciej Korwin i oddał w zastaw Hynkowi z Podiebradów, natomiast Rybnik i Żory (oraz połowa Baborowa) stały się zastawami jego wierzycieli. Z księstwem karniowskim król Maciej Korwin obszedł się nie mniej surowo, konfiskując Janowi Starszemu część karniowską (1474), a następnie przejmując część wodzisławską po bezpotomnej śmierci księcia (1483). Zabiegi sióstr zmarłych braci, Małgorzaty oświęcimsko-zatorskiej i Barbary oświęcimskiej, o odzyskanie schedy po nich zakończyły się tylko połowicznym sukcesem. Małgorzata po kilkuletniej batalii zrezygnowała (za odszkodowaniem) ze swych praw do Rybnika i Żor na rzecz Jana IV Młodszego raciborskiego, natomiast przegrała spór o okręg pszczyński z księciem Kazimierzem cieszyńskim, ówczesnym władcą tego terytorium. Barbara z kolei, wykorzystując śmierć króla Macieja Korwina (1490), próbowała odzyskać Karniów, ale ostatecznie udało jej się tylko współrządzić (do śmierci) w księstwie karniowskim ze swym zięciem Jerzym z Šelmberka, który został nowym dziedzicem na mocy decyzji króla Władysława Jagiellończyka.

\section{Bibliografia}

\section{Źródła rękopiśmienne}

Archiwum Państwowe w Katowicach, Oddział w Pszczynie: Archiwum Ksiązat Pszczyńskich, dok. sygn. II-15, II-16, II-18, II-34, II-38; Ksiegga radziecka miasta Pszczyny (1466-1544), sygn. M Pna 369.

Centrum Informacji Naukowej i Biblioteka Akademicka w Katowicach: Copiarius monasteri ad S. Venceslaum. Diplomatarius Silesiacarum — mikrofilm syg. Mf. 166, 1-2 (oryginał w Bibliotece Narodowej w Pradze, sygn. 6 XVI 8).

\section{Źródła drukowane}

Archiv český, čili staré písemné pámatky české i moravské. Díl. 4, 5, 15, 18. Edd. F. PalackÝ, J. KalouseK. Praga 1846, 1862, 1896, 1900.

BeLlerode B.: Geschichtlische Untersuchungen über die Plessner Lehnsurkunden 1474-1500. In: B. Bellerode: Beiträge zur Schlesischen Rechtsgeschichte. Heft 1. Breslau 1897.

Bellerode B.: Urkunden über die Besitz- und Rechts-Verhältnisse der Herrschaft Pless 15171854. In: B. Bellerode: Beiträge zur Schlesischen Rechtsgeschichte. Heft 2. Breslau 1898. 
Codex diplomaticus Poloniae. T. 4. Wyd. M. Boвowski. Warszawa 1887.

Codex diplomaticus Silesiae. Bd. 2, 6. Hrsg. W. Wattenbach, C. Grünhagen. Breslau 1859, 1865.

Eschenloher P.: Historia Wratislaviensis. Hrsg. H. Margraf. In: Scriptores rerum Silesiacarum. Bd. 7. Breslau 1872.

Jana Dlugosza Roczniki czyli Kroniki sławnego Królestwa Polskiego. Ks. 12. Tłum. J. MruKównA. Warszawa 2004, 2006.

Joannis Dlugossii Annales seu cronicae incliti Regni Poloniae. Lib. 12. Ed. J. Wyrozumski. Warszawa 2003-Kraków 2005.

Katalog średniowiecznych dokumentów przechowywanych $w$ Archiwum Państwowym we Wrocławiu. Wyd. R. Stelmach. Wrocław-Racibórz 2014.

Lehns- und Besitzurkunden Schlesiens und seiner einzelnen Fürstenthümer im Mittelalter. Hrsg. C. Grünhagen, H. Markgraf. T. 1-2. Leipzig 1881-1883.

Listinář Těšinska. Codex diplomaticus ducatus tesinensis. Sv. 3: 1460-1495. Zprac. E. NĚMeC. Český Těšín 1960.

Listinář Těšinska. Codex diplomaticus ducatus tesinensis. Sv. 4: 1495-1526. Zprac. E. NĚMeC. Český Těšín 1961.

Materiały do dziejów wielkich Katowic (1299-1799). Wyd. L. Musıot. Katowice 1936 (Pamiętnik Instytutu Śląskiego, T. 2).

Musioe L.: Dokument sprzedaży Księstwa Pszczyńskiego z dn. 21 lutego 1517 r. „Roczniki Towarzystwa Przyjaciół Nauk na Śląsku” 1930, T. 2.

Opavský Listinář. Díl. 5. Ed. F. ŠIGUT. Opava 1996.

Politische Correspondenz Breslaus im Zeitalter des Königs Matthias Corvinus (1469-1479). Hrsg. B. Kronthal, H. Wendt. In: Scriptores rerum Silesiacarum. Bd. 13. Breslau 1893.

Ratiborer Chronik. Hrsg. A. Weltzel. „Zeitschrift des Vereins für Geschichte und Alterthum Schlesiens" 1862, Bd. 4.

SCHAEFFER H.W.F.: Kronika wolnego państwa stanowego a od 1827 r. księstwa pszczyńskiego. Cz. 1-2. Wyd. B. Spyra. Pszczyna 1997.

Silesiacarum Rerum Scriptores. Bd. 1. Hrsg. F. Sommersberg. Lipsiae 1729.

Starodawne prawa polskiego pomniki. T. 2: Z ksiag rękopiśmiennych dotąd nie użytych, głównie zaś z ksiag dawnych sądowych ziemskich i grodzkich ziemi krakowskiej. Wyd. Z. HeLCEL. Kraków 1870.

Zimmermann F.: Beyträge zur Beschreibung von Schlesien. Bd. 2. Brieg 1783.

\section{Opracowania}

BaczKowski K.: Walka Jagiellonów z Maciejem Korwinem o koronę czeska w latach 14711479. Kraków 1980.

Biermann G.: Geschichte der Herzogthümer Troppau und Jägerndorf. Teschen 1874.

BlažeK C.: Der abgestorbene Adel der preussischen Provinz Schlesien. Th. 1. Nürnberg 1887.

ČAPSKÝ M.: Górny Ślask w okresie późnego średniowiecza (1327-1526). W: Historia Górnego Śląka. Polityka, gospodarka i kultura europejskiego regionu. Red. J. BAHLCKE, D. GAWRECKI, R. KaCZMAReK. Gliwice 2011. 
ČAPSKÝ M., RADEK D.: Paralela ke zhořeleckému vévodství? K rodové politice Matyáše Korvina v Horním Slezsku. „Historie - Otázky - Problémy” 2015, 1 (7).

Сносноlatý F.: Genealogie opavských Přemyslovců 1255-1525. „Listy Genealogické a Heraldické Společnosti v Praze. Acta Genealogica ac Heraldica” 1978, ̌̌. 6.

DworzaczeK W.: Genealogia. T. 2. Warszawa 1959.

DZIEwUlski W.: Dzieje Raciborza od najdawniejszych czasów do zaboru Ślaska przez Prusy. W: Szkice z dziejów Raciborza. Katowice 1967.

Fukala R.: Jiři ze Šelmberka. V: Biografický slovník Slezska a severní Moravy. Č. 11. Ostrava 1998.

Górecki T., WieczoreK M.: Książęta Górnego Śląska. Wybór postaci. Żory 2008.

Grotefend H.: Stammtafeln der schlesischen Fürsten bis zum Jahre 1740. Breslau 1889.

HoRváth R.: Itineraria regis Matthiae Corvini et regine Beatricis de Aragonia (1458 - [1476]1490). Budapest 2011.

Hyckel G.: Geschichte der Stadt Ratibor. Das Mittelalter. Augsburg 1956.

IDZIKowsKi F.: Geschichte Stadt und ehemaligen Herrschaft Rybnik in Oberschlesien. Breslau 1861.

JASIŃSKi K.: Rodowód Piastów ślaskich. Kraków 2007.

Jurek T.: Panowie z Wierzbnej. Studium genealogiczne. Kraków 2006.

Kalous A.: Matyáš Korvín (1443-1490). Uherský a český král. České Budějovice 2009.

Kiryk F.: Małgorzata (Machna). W: Polski stownik biograficzny. T. 19. Kraków 1974.

Kopetzky F.: Zur Geschichte und Genealogie der Přemyslidischen Herzoge von Troppau. „Archiv für österreichische Geschichte“ 1869, Bd. 41.

KouřIl P., Winoda M., Prix D.: Hrady českého Slezska. Brno-Opava 2000.

KrejČí T.: Jan (kolem r. 1435 † 1483). V: Biografický slovnik Slezska a severní Moravy. Č. 4. Opava-Ostrava 1995.

KrejČíK T.: Přemyslovci Opavští. V: Biografický slovník Slezska a severní Moravy. Č. 4. Opava-Ostrava 1995.

KreJČ́́K T.: Václav (okolo 1440 † 1478). V: Biografický slovník Slezska a severní Moravy. Č. 4. Opava-Ostrava 1995.

Ksiązęta i księżne Górnego Śląska. Red. A. BarciaK. Katowice 1995.

Kubiciel R.: Ziemia pszczyńska i jej właściciele do połowy XVI wieku. W: Ziemia pszczyńska przez wieki. Stan badań, archiwalia, problemy badawcze. Red. A. Barciak. Suszec 2002.

Mika N.: Dzieje ziemi raciborskiej. Kraków 2010.

Mıka N.: Przemyślidzi opawsko-raciborscy. Blaski i cienie panowania. „Ziemia Raciborska. Rocznik historyczno-przyrodniczy" 2006, 9 (69).

Musiol L.: Najstarszy protokół miasta Pszczyny. „Roczniki Towarzystwa Przyjaciół Nauk na Śląsku" 1931, T. 3.

Musioe L.: Pszczyna. Monografia historyczna. Katowice 1936.

Opava. Edd. K. Müller, R. Ž́́ćEK. Praha 2006.

PalackÝ F.: Dějiny národu českého v Čechách a v Moravě. Praha 1908.

PANIC I.: Śląsk Cieszyński w średniowieczu (do 1528 roku). Cieszyn 2010.

PANIC I.: Żory pod rządami Przemyślidów i Habsburgów. Z badań nad historiq miasta w latach 1327-1742. Żory 2002.

Pietrzyk I.: Kancelaria i dokument Przemyślidów opawskich $w X I V-X V$ wieku. Katowice 2008

PilnáČEK J.: Rody starého Slezska. Díl. 1-5. Brno 1991.

Pindur D.: Książę czasów przełomu. Kazimierz II cieszyński (1459-1528) i jego władztwo. Wrocław 2010. 
Polak J.: Poczet panów i książą pszczyńskich. Cz. 1. Pszczyna 2007.

Prus K.: Z przeszłości Mikołowa i jego okolicy. Mikołów 1996.

Rajman J.: Jan (Janusz) IV. W: Piastowie. Leksykon biograficzny. Red. S. Szczur, K. OżóG. Kraków 1999.

Rajman J.: Pogranicze śląsko-matopolskie w średniowieczu. Kraków 1998.

ŠEFČ́́K E.: Barbara (ok. 1445-1510/1511). W: Książęta i księżne Górnego Ślaska. Red. A. BARCIAK. Katowice 1995.

Słownik historyczno-geograficzny województwa krakowskiego w średniowieczu. Cz. 1. Oprac. J. Laberschek, Z. Leszczyńska-Skrętowa, F. Sikora, J. Wiśniewski. Wrocław-Kraków 1980-1986.

Sperka J.: Do 1532 roku. W: Rybnik. Dzieje miasta i jego dzielnic. Red. Z. HoJka, B. Kloch. T. 1. Rybnik 2017.

SPERKA J.: Kazimierz Jagiellończyk wobec ksiąząt i księstw górnośląskich. Zarys relacji politycznych. W: Jagiellonowie $i$ ich świat. Dynastia królewska $w$ drugiej połowie XV $i$ w XVI wieku. Red. B. Czwojdrak, J. Sperka, P. WęCowski. Kraków 2016.

SPERKa J.: Koligacje rodzinne Przemyślidów opawskich linii raciborskiej z możnowładztwem Królestwa Polskiego do początku XVI wieku. „Średniowiecze Polskie i Powszechne” 2019, T. 11 (15).

SPERKA J.: Matżeństwa Mikołaja $V$ księcia opawsko-raciborskiego pana na Rybniku (zm. 1452 r.). W: Silesia - Polonia - Europa. Red. J. SPERKA. Katowice-Bielsko-Biała 2019.

Sperka J.: Pszczyna i ziemia pszczyńska - dzieje polityczne do 1517 roku. W: Pszczyna. Monografia historyczna. Red. R. Kaczmarek, J. Sperka. Pszczyna 2014.

SPERKA J.: Tragiczne losy księcia rybnickiego Wacława III (zm. 1478). Epizod z dziejów rywalizacji między Jagiellonami a Maciejem Korwinem o koronę czeska. „Studia z Dziejów Średniowiecza" 2016, T. 20.

Stibor J.: Bruntálští z Vrbna. V: Biografický slovník Slezska a severní Moravy. Č. 10. Ostrava 1998.

TęGowski J.: Pierwsze pokolenia Giedyminowiczów. Poznań-Wrocław 1999.

TRUnKhardt A.: Kronika Rybnicka. (Dzieje miasta Rybnika i dawniejszego państwa rybnickiego na Górnym Ślasku na podstawie wydanej w 1861 r. Kroniki Franciszka Idzikowskiego). Rybnik 1925.

TuREK A., JISL L.: Ostravsko za česko-uherské válký ve světle písmných pramenů i archeologických nálezů. „Časopis Slezského muzea. Serie B — védy historické” 1953, 3.

Weltzel A.: Geschichte der Stadt Sohrau in Oberschlesien. Sohrau 1888.

Weltzel A.: Geschichte der Stadt und Herrschaft Ratibor. Ratibor 1881.

Weltzel A.: Historia miasta Żory na Górnym Ślasku. Żory 1997.

ZIVIER E.: Geschichte des Fürstentums Pless. Bd. 1. Kattowitz 1906. 
Jerzy Sperka

The Duchy of Karniów and Rybnik and its history till the beginning of the sixteenth century

Summary

The Duchy of Karniów [Krnov] and Rybnik was established in 1437 as a result of dividing the inheritance that was left by Jan II Żelazny [the Iron-born], the Duke of Racibórz. The duchy was inherited by his son Mikołaj and it retained its territorial integrity till 1465/1466. This is when Jan Starszy [the Elder] and Vaclaus III, who were Mikołaj's sons, carried out a division that resulted in the establishment of two duchies. The first duchy was the Duchy of Karniów (including Karniów, Bruntal, and Wodzisław) and the other was the Duchy of Rybnik (including Rybnik, Żory, and Pszczyna). What had a pervasive influence on the history of those two small duchies was the war over the Czech crown, which took place in the 1470s between the Jagiellonians and Maciej Korwin. The two brothers were forced to monoeuvre between the two sides of the conflict, which led to rejection of them and treason accusations by both sides of the conflict. Vaclaus ruled unreasonably and then died without an heir in 1478, which brought an end to the Duchy of Rybnik. The Pszczyna part was confiscated by King Maciej Korwin and it was put in pledge with Hynek of Podiebrady. Rybnik and Żory (and half of Baborów) were put in pledge as well. In the case of the Duchy of Karniów King Maciej Korwin was equally intransigent, since he confiscated the Karniów part from Jan Starszy [The Elder] (1474) and took over the Wodzisław part after the duke's death without an heir (1483). The sisters of the late dukes, Duchess Margaret of Oświęcim and Zator and Barbara of Oświęcim, made efforts to regain the inheritance, but the success was only partial. After a few years' battle Margaret gave up her rights to Rybnik and Żory (with compensation) and handed them over to Jan IV Młodszy [the Younger] of Racibórz. She lost the competition over the Pszczyna district that she had entered with Duke Casimir of Cieszyn. In turn, Barbara used the death of King Maciej Korwin (1490) to try to regain Karniów, but she only managed to co-rule (till her death) in the Duchy of Karniów with her son-in-law Jiři of Šelmberk, who became the new heir in accordance with the decision made by King Ladislaus the Jagiellonian.

Keywords: Silesian dukes, Přemyslids of Opava, medieval Silesia, Rybnik, Krnov, UpperSilesian Piast dynasty

Jerzy Sperka

Das Herzogtum Jägerndorf-Rybnik und dessen Geschichte bis Anfang des sechzehnten Jahrhunderts

Zusammenfassung

Das Herzogtum Jägerndorf-Rybnik entstand 1437 durch Teilung der Erbschaft nach dem Herzog von Ratibor, Johann II. dem Eisernen. Es wurde seinem älteren Sohn Nikolaus zuteil und wahrte die territoriale Einheit bis 1465/1466, als Johann der Ältere und Wenzel III. (die Söhne von Nikolaus) die Gebiete teilten, was die Entstehung des Herzogtums Jägerndorf (mit Jägerndorf, Freudenthal und Loslau) und des Herzogtums Rybnik (mit Rybnik, Sohrau, Pleß) zur Folge hatte. Einen wesentlichen Einfluss auf die spätere Geschichte dieser kleinen Her- 
zogtümer hatte der Krieg um die böhmische Krone, der in den 1470er Jahren zwischen den Jagiellonen und Matthias Corvinus ausgetragen wurde. Der Streit zwang die Brüder, zwischen den Konfliktparteien zu lavieren, was in kurzer Zeit zu gegenseitigen Anfeindungen und Verratsbeschuldigungen führte. Durch das unüberlegte Handeln Wenzels wurde das Herzogtum Rybnik nach seinem nachkommenlosen Tod (1478) aufgelöst. Das Pleßer Gebiet wurde vom König Matthias Corvinus beschlagnahmt und an Hynek von Podiebrad verpachtet, Rybnik und Sohrau (und die Hälfte von Bauerwitz) wurden hingegen verpfändet. Mit dem Herzogtum Jägerndorf ging der König Matthias Corvinus ebenso hart um, indem er das Jägerndorfer Gebiet von Johann dem Älteren konfiszierte und, als der Herzog nachkommenlos starb (1483), auch den Loslauer Teil übernahm. Die Bemühungen der Schwerstern der verstorbenen Brüder Herzoginnen Margarete von Auschwitz-Zator und Barbara von Auschwitz, das Familienerbe wiederzubekommen, waren nur halb erfolgreich. Nach einem mehrjährigen Streit verzichtete Margarete (gegen eine Entschädigung) auf ihre Ansprüche auf Rybnik und Sohrau zugunsten Johann IV. des Jüngeren von Ratibor, verlor jedoch den Streit mit dem Herzog Kasimir von Teschen um das Pleßer Gebiet. Barbara versuchte hingegen, nach dem Tod des Königs Matthias Corvinus (1490) Jägerndorf zurückzubekommen, aber letzten Endes durfte sie lediglich (bis zum Tod) das Herzogtum Jägerndorf zusammen mit ihrem Schwiegersohn, Georg von Schellenberg, der kraft Entscheidung des Königs Vladislav II. zum neuen Erben wurde, mitregieren.

Schlüsselwörter: Herzöge von Schlesien, Troppauer Přemysliden, Schlesien im Mittelalter, Rybnik, Jägerndorf, Oberschlesische Piasten 